\title{
БОЛЬОВИЙ СИНДРОМ ТА РЕАКЦІЯ СИНОВІАЛЬНОЇ ОБОЛОНКИ КОЛІННОГО СУГЛОБА НА ЗАСТОСУВАННЯ КРІОТЕРАПІЇ З РЕГУЛЬОВАНИМ ІМПУЛЬСНИМ СТИСНЕННЯМ У ПАЦІЄНТІВ ПІСЛЯ АРТРОСКОПІЧНОӦ ПАРЦІАЛЬНОЇ МЕНІСКЕКТОМІї
}

\author{
๑Ю. О. Грубар, Ю. Ю. Грубар \\ Тернопільський національний медичний університет імені І. Я. Горбачевського МОЗ України
}

РЕзЮМЕ. Серед усіх травм нижньої кінцівки частота ушкоджень колінного суглоба становить до 75 \% випадків. Серед ушкоджень колінного суглоба, які найчастіше трапляються, переважають розриви менісків, на їх частку припадає від 32 \% до 85 \% випадків травм. 3 середини 1980-х років артроскопічні хірургічні втручання стали «золотим стандартом» у лікуванні розривів менісків і остаточно показали свою ефективність в порівнянні з відкритою артротомією. Однак оперативне втручання, навіть малотравматичне, викликає больовий синдром та розвиток реактивного синовіїту колінного суглоба, усунення якого в найкоротші терміни дозволяє прискорити реабілітацію. Вважається що використання холоду - це один із найпоширеніших засобів, що використовується як ефективне нефармакологічне втручання для лікування больового синдрому при травмах. Найчастіше вказують на такі ефекти від застосування кріотерапії - зняття болю, зменшення запального набряку і ліквідація м'язового спазму. Результат холодового впливу залежить як від кількості та швидкості тепла, що відводиться з травмованої ділянки, так і від характеру загальної та місцевої реакції організму на вплив низьких температур.

Мета - вивчити ефективність застосування кріотерапії з регульованим імпульсним стисненням у пацієнтів після артроскопічної парціальної меніскектомії для зниження інтенсивності больового синдрому та проявів післяопераційного реактивного синовіїту.

Матеріал і методи. Всього під спостереженням перебували 50 пацієнтів. Їх було поділено на дві групи: контрольну та експериментальну, по 25 пацієнтів у кожній. До експериментальної групи увійшли 25 пацієнтів (18 чоловіків і 7 жінок) у віці від 18 до 43 років (середній вік - 31,2 року). До контрольної групи увійшли 25 пацієнтів (16 чоловіків і 9 жінок) у віці від 18 до 42 років (середній вік - 32,6 року). 3 метою визначення ефективності застосування кріотерапії з регульованим імпульсним стисненням при больовому синдромі та реакції синовіальної оболонки колінного суглоба у пацієнтів після проведеної парціальної меніскектомії в перші години в експериментальній групі застосовували систему «GIOCO CRYO - 2». При включенні приладу ділянка суглоба періодично стискалася манжетою з циклом в 30 секунд (10 секунд стиснення, 20 секунд релаксація). Швидкість подачі охолодженої рідини становила до 7 літрів на хвилину. Ї̈̈ температура коливалася в межах 11-13 градусів Цельсія. В контрольній групі застосовували мішечки з льодом. Тривалість процедури в обох групах становила 15 хвилин.

Висновки. Дані, отримані в процесі дослідження, свідчать про доцільність впровадження у повсякденну практику кріотерапії з регульованим імпульсним стисненням з метою ранньої реабілітації пацієнтів після проведеної парціальної меніскектомії.

КлючОВІ СлОВА: травма; пошкодження менісків; колінний суглоб; кріотерапія з регульованим імпульсним стисненням; артроскопія; меніскектомія.

Вступ. У зв'язку зі збільшенням кількості людей, які займаються спортом та активним відпочинком, частота випадків травматичних ушкоджень колінного суглоба зростає та становить близько 75 \% випадків усіх травм нижньої кінцівки [5]. Вони трапляються у людей будь-якого віку, статі та при усіх рівнях активності. Серед ушкоджень колінного суглоба, які трапляються найчастіше, переважають розриви менісків - на їх частку припадає від 32 \% до 85 \% випадків [8]. Згідно зі статистичними даними, пошкодження менісків виникають у 60 - 70 випадках на 100000 осіб протягом року [9]. Найчастішим механізмом їх пошкодження $\epsilon$ стресові перевантаження, що виникають у результаті раптового прискорення або уповільнення В поєднанні зі зміною напрямку руху [12].

3 середини 1980-х років артроскопічні хірургічні втручання стали «золотим стандартом» у лікуванні розривів менісків і остаточно показали свою ефективність у порівнянні з відкритою артротомією [13]. Значне поширення малоінвазивної хірургії змусило переглянути схеми післяопераційного ведення пацієнтів. Зокрема, після артроскопічних меніскектомій практично відпала необхідність у тривалому застосуванні наркотичних анальгетиків у післяопераційному періоді. Однак оперативне втручання, навіть малотравматичне, викликає больовий синдром та розвиток реактивного синовіїту колінного суглоба, усунення якого в найкоротші терміни дозволяє прискорити реабілітацію. 3 цією метою часто застосовують нестероїдні протизапальні препарати (НПЗП), які, поряд із позитивними властивостями, мають побічну дію, що не завжди безпечно, насамперед для пацієнтів, які мають супутні захворювання шлунково-кишкового тракту [2].

Вважають, що використання холоду (кріотерапія) - це одне із найпоширеніших та найефективніших нефармакологічних утручань для лікування больового синдрому при травмах [7]. Най- 
Огляди літератури, оригінальні дослідження, погляд на проблему, випадок з практики, короткі повідомлення частіше вказують на такі ефекти від застосування кріотерапії- зняття болю, зменшення запального набряку і ліквідація м'язового спазму [14]. Результат холодового впливу залежить як від кількості, так і від швидкості тепла, що відводиться з травмованої ділянки, а також від характеру загальної та місцевої реакції організму на вплив низьких температур.

Мета - вивчити ефективність застосування кріотерапії з регульованим імпульсним стисненням у пацієнтів після артроскопічної парціальної меніскектомії для зниження інтенсивності больового синдрому та проявів післяопераційного реактивного синовіїту.

Матеріал і методи дослідження. Всього під спостереженням перебували 50 пацієнтів. Їх було поділено на дві групи: контрольну та експериментальну, по 25 пацієнтів у кожній. До експериментальної групи увійшли 25 пацієнтів (18 чоловіків і 7 жінок) у віці від 18 до 43 років (середній вік 31,2 року), до контрольної групи порівняння увійшли 25 пацієнтів (16 чоловіків і 9 жінок) у віці від 18 до 42 років (середній вік - 32,6 років). В обох групах в загальному проведено 50 парціальних меніскектомій. Всі оперативні втручання проводилися на медіальному меніску. Оперативне втручання проходило під провідниковою анестезією і тривало не більше 30 хвилин. Пацієнти належали до I та II класів анестезіологічного ризику згідно зі шкалою ASA.

Клінічне обстеження пацієнтів проводили за такою схемою: вивчали анамнез та механізм виникнення травми, проводили пальпацію суглоба та його огляд, визначали клінічні симптоми, що вказували на ушкодження менісків колінного суглоба. Окрім цього, обов'язково проводили його рентгенографію в двох проекціях, ультразвукове дослідження та магніторезонансну томографію суглоба.

За основними клінічними показниками, які включали вік, стать, дані об'єктивного обстеження, характер захворювання, хворі обох груп були зіставними. Парціальна меніскектомія як оперативне втручання забезпечила більш контрольовані умови для оцінки ролі кріотерапії в дослідженні післяопераційного болю та реактивного синовіїту в ранньому післяопераційному періоді. Отже, такі дослідження мають кращу методологічну якість, і висновки можуть поліпшити вірогідність застосування кріотерапії у пацієнтів після проведеної меніскектомії.

Для забезпечення анестезії при оперативних втручаннях ми використовували провідникову анестезію в комбінації із внутрішньовенним наркозом. Іїі виконували за допомогою нейроелектростимулятора Stimuplex XHC-12. Пошук нерво-

вих волокон (сідничного та стегнового нервів) проходив із використанням відносно високої амплітуди струму - 0,8 мА при ширині імпульсу 0,1 мс. При отриманні нейром'язової відповіді амплітуду струму зменшували до 0,4 мА і при збереженні даної реакції після неодноразових аспіраційних проб вводили розчин місцевих анестетиків [10].

3 метою визначення ефективності застосування кріотерапії з регульованим імпульсним стисненням при больовому синдромі у пацієнтів після проведеної парціальної меніскектомії в перші години в експериментальній групі застосовували систему "GIOCO CRYO-2». Система GIOCO CRYO-2 складається з помпи, манжет для стиснення ділянки суглоба і мікропроцесора, що керує помпою (рис. 1).

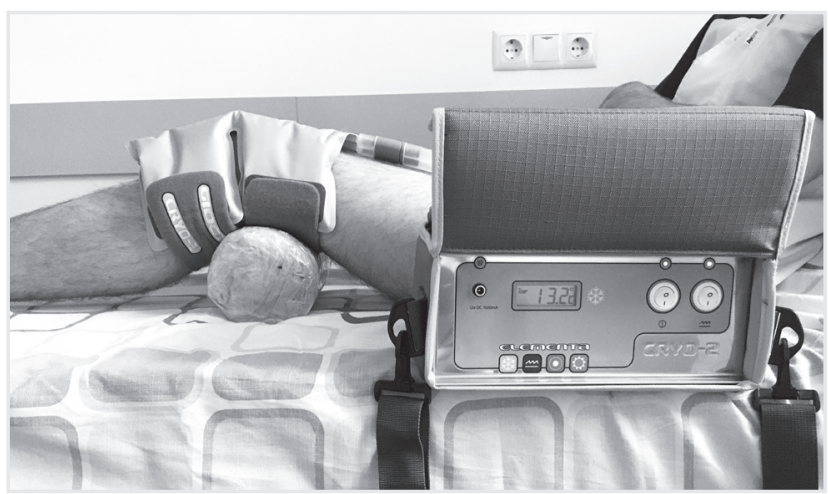

Рис. 1. Зовнішній вигляд системи «GIOCO CRYO-2».

Резервуар, що підключений до помпи, заповнювали льодом і водою. Подвійними трубками з'єднували манжету з помпою. При включенні приладу ділянка суглоба періодично стискалася манжетою з циклом в 30 секунд (10 секунд стиснення, 20 секунд релаксація). Швидкість подачі охолодженої рідини становила до 7 літрів на хвилину. Температура охолодженої рідини коливалася в межах 13-15 градусів Цельсія. Прилад працював від акумулятора, що дозволяло його використовувати в умовах стаціонару та для амбулаторного лікування. В контрольній групі для місцевої кріотерапії застосовували мішечки з льодом. Тривалість процедури в обох групах становила по 15 хвилин двічі на день.

Больовий синдром оцінювали за бальною візуальною аналоговою шкалою (ВАШ). Відстань між початком відрізка («болю немає») і зробленою відміткою вимірювали в сантиметрах і округлювали до цілого. Кожен сантиметр на лінії відповідав 1 балу. При позначці до 2 см біль класифікували як слабкий, від 2 до 4 см - помірний, від 4 до 6 см - сильний, від 6 до 8 см - виражений і до 10 см - нестерпний [11].

Дослідження проводили щоденно, з першого післяопераційного дня по десятий день 
Огляди літератури, оригінальні дослідження, погляд на проблему, випадок з практики, короткі повідомлення включно. В перший операційний день на тлі застосування кріотерапії з регульованим імпульсним стисненням в експериментальній групі середнє значення больового синдрому за ВАШ становило $(5,80 \pm 0,12)$ бала. В контрольній групі

при використанні традиційної методики проведення кріотерапії середнє значення больового синдрому за ВАШ становило $(6,36 \pm 0,15)$ бала, що відповідає показникам сильного болю (рис. 2).

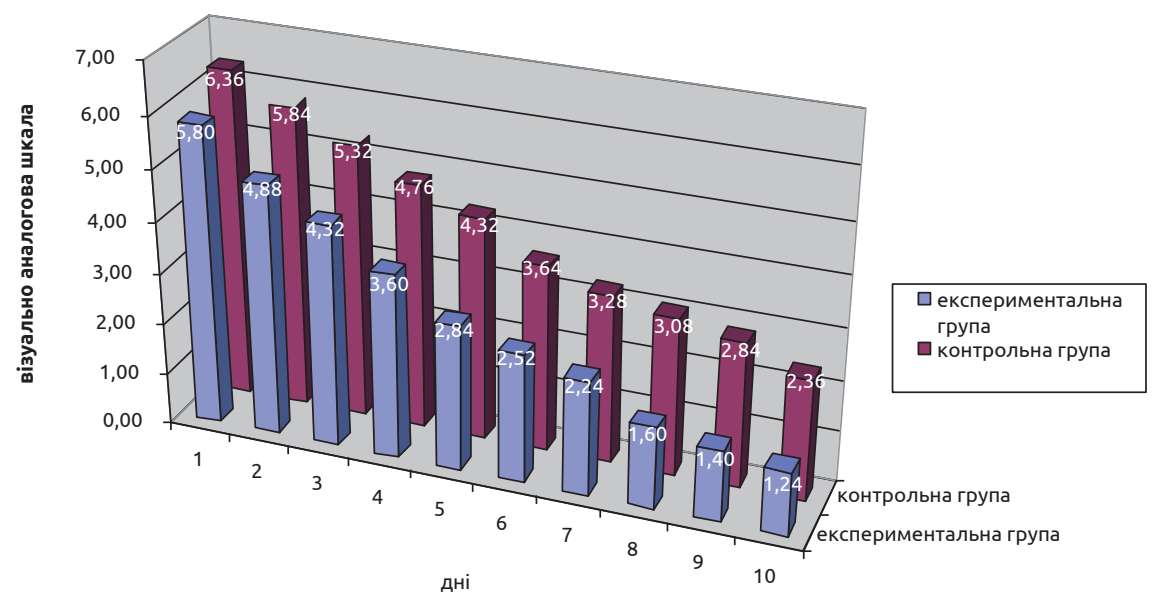

Рис. 2. Динаміка показника больового синдрому в пацієнтів експериментальної та контрольної груп у післяопераційному періоді (за ВАШ).

В динаміці у пацієнтів експериментальної групи на п'яту добу з моменту проведення оперативного втручання середнє значення больового синдрому за ВАШ становило $(2,84 \pm 0,17)$ бала (помірний біль), тоді як у контрольній групі цей показник становив $(4,35 \pm 0,09)$ бала (сильний біль). Отже, больовий синдром у пацієнтів експериментальної групи був у 1,5 раза меншим, ніж у осіб контрольної групи.

Прогресуюче зменшення інтенсивності больового синдрому в експериментальній групі дозволило в перші дні після оперативного втручання в більшості пацієнтів удвічі зменшити застосування знеболювальних препаратів. Така ж відмінність збереглася до десятого дня після проведення оперативного втручання. Інтенсивність болю в експериментальній групі становила $(1,24 \pm 0,13)$ бала, в контрольній групі - $(2,36 \pm 0,10)$ бала.

Отже, використання кріотерапії з регульованим імпульсним стисненням показало свою ефективність у зниженні інтенсивності больового синдрому в пацієнтів після парціальної меніскектомії.

Ексудативний компонент запалення не настільки відчутний для хворого, як больовий синдром, але має виняткове значення як об'єктивний показник активності синовіїту. Реактивний запальний асептичний процес у суглобі - необхідна захисна реакція тканин на пошкодження [3], однак доволі часто він набуває надмірного характеру, що зумовлює його тривалий, а інколи й затяжний перебіг, що може викликати розвиток ускладнень [6].
Ступінь вираженості реактивного асептичного синовіїту оцінювали за наявністю клінічних ознак (больовий синдром, позитивний симптом «балотування надколінника») та додаткових методів дослідження, а саме сонографії.

Сонографія все частіше застосовується з метою дослідження внутрішніх структур колінного суглоба і $\epsilon$ цінним неінвазивним діагностичним інструментом для оцінки патології його капсульнозв'язкового апарату. Особливо вона ефективна завдяки здатності ультразвуку візуалізувати зазначеніструктури в динаміці [1]. Важливим компонентом дослідження було визначення впливу кріотерапії в режимі регульованого імпульсного стиснення на товщину синовіальної оболонки і ексудативні зміни у суглобі після артроскопічної парціальної меніскектомії.

Для об'єктивізації впливу кріотерапії з регульованим імпульсним стисненням на симптоми синовіїту в динаміці проводили УЗД колінних суглобів на апараті Acuson Antares (Siemens) із використанням високочастотного широкосмугового датчика з робочою частотою 7-12 МГц. Дослідження проводили в 3 етапи. Перше дослідження виконували в перший післяопераційний день; наступне дослідження - в день виписування пацієнтів із стаціонару, на 2-3 добу з моменту виконання оперативного втручання; третє обстеження - в момент знімання швів, на 10 добу післяопераційного періоду. Виділяли такі ступені потовщення синовіальної оболонки: 0 - відсутність гіпоехогенних структур або їх товщина <2 мм; І ступінь - товщина сино- 
Огляди літератури, оригінальні дослідження, погляд на проблему, випадок з практики, короткі повідомлення віальної оболонки 2-4 мм; II ступінь - товщина оболонки 4-6 мм; III ступінь - товщина синовіальної оболонки >6 мм. 3 метою визначення градації накопичення реактивної синовіальної рідини в верхніх заворотах колінного суглоба застосовували таку шкалу: 0 - відсутність рідини в порожнині суглоба, I - максимальна товщина шару рідини <2 мм; II - товщина шару рідини 2-4 мм, III - товщина шару рідини >4 мм [4].

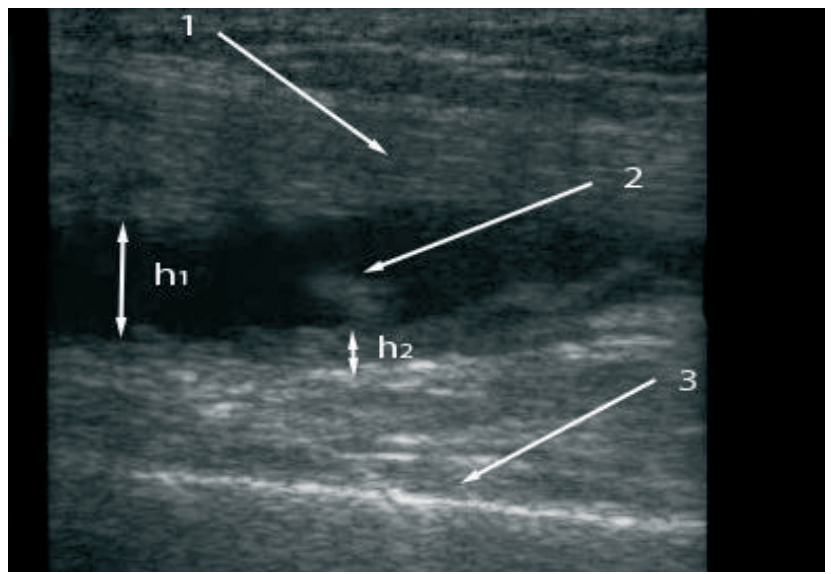

Рис. 3. Товщина синовіальної оболонки колінного суглоба при сонографічному дослідженні пацієнтів експериментальної групи на першу добу після парціальної меніскектомії: 1 - сухожилок чотириголового м'яза стегна; 2 - фібриновий згусток та реактивна рідина в верхньому завороті колінного суглоба; 3 -кортикальний шар стегнової кістки; $\mathrm{h}_{1}$ - висота шару реактивної рідини в верхньому завороті колінного суглоба; $h_{2}$ - товщина синовіальної оболонки.
При сонографічному дослідженні синовіальної оболонки пацієнтів експериментальної групи виявлено, що іії товщина на першу добу після втручання становила від 4,1 до 2,5 мм (рис. 3), середній показник іiї товщини становив $(3,15 \pm$ $0,11)$ мм. У контрольній групі ці показники становили відповідно від 4,2 до 2,5 мм (рис. 4), середній показник її товщини становив $(3,19 \pm 0,09)$ мм (рис. 5).

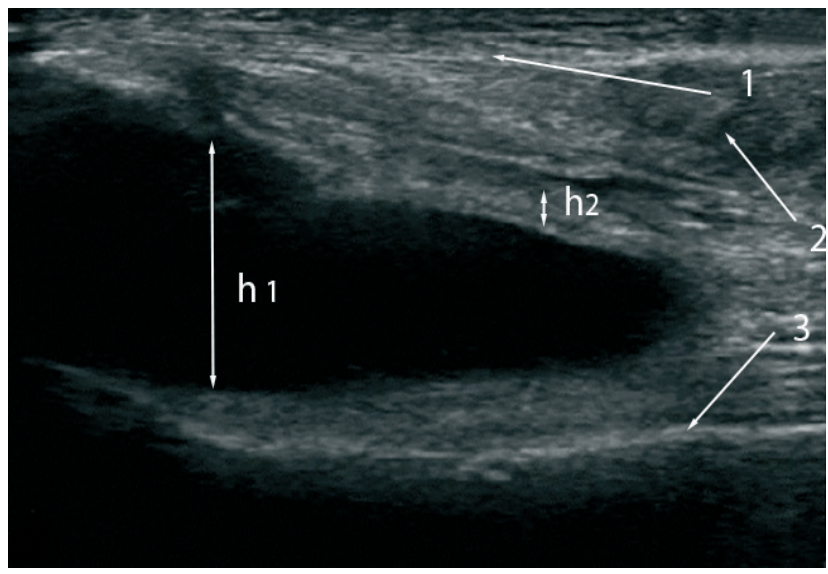

Рис. 4. Товщина синовіальної оболонки колінного суглоба при сонографічному обстеженні пацієнтів контрольної групи на першу добу після парціальної меніскектомії: 1 - сухожилок чотириголового м'яза стегна; 2 - м'язова тканина; 3 - кортикальний шар стегнової кістки; $\mathrm{h}_{1}$ - висота шару реактивної рідини в верхньому завороті колінного суглоба; $h_{2}$ - товщина синовіальної оболонки.

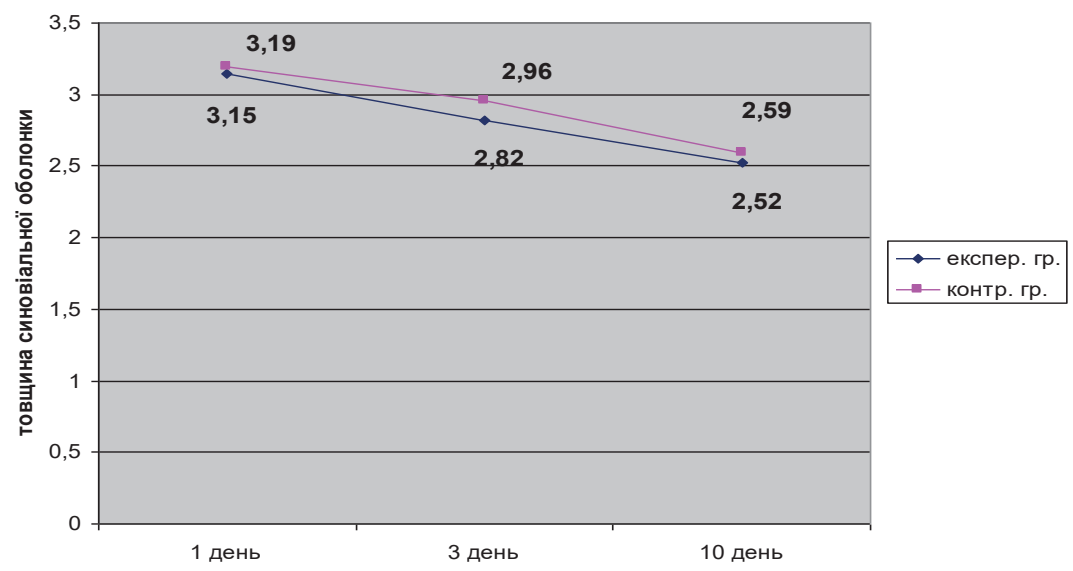

Рис. 5. Зміна товщини синовіальної оболонки колінного суглоба в експериментальній та контрольній групах під впливом кріотерапії з регульованим імпульсним стисненням.

У процесі динамічного спостереження за пацієнтами обох груп на 3 та 10 добу з моменту оперативного втручання виявлено такі зміни в товщині синовіальної оболонки колінного суглоба. В експериментальній групі на третій день після оперативного втручання середній показник її товщини становив $(2,82 \pm 0,11)$ мМ, в контрольній групі, відповідно, $(2,96 \pm 0,11)$ мм (рис. 5).

На десятий день після втручання показники були наступними: в експериментальній групі товщина синовіальної оболонки становила $(2,52 \pm 0,09)$ мм, у контрольній - $(2,59 \pm 0,09)$ мм. 
Огляди літератури, оригінальні дослідження, погляд на проблему, випадок з практики, короткі повідомлення

Отже, середньостатистичні дані свідчать про те, що в обох групах товщина синовіальної оболонки мала приблизно однакову товщину на усіх етапах дослідження (рис. 5).

Висота шару реактивного ексудату на першу добу після втручання в порожнині суглоба контрольної групи становила в середньому $(2,76 \pm 0,08)$ мм (рис. 6) що майже 1,3 раза більше, ніж в експериментальній $(2,16 \pm 0,12)$ мм (рис. 7).

Проводячи сонографію у пацієнтів обох груп на третю та десяту доби з моменту оперативного втручання ми встановили, що в обох групах кількість реактивного ексудату поступово зменшувалася. В експериментальній групі ці показники були такими: на третій день висота шару реактивного ексудату становила в середньому $(1,84 \pm 0,14)$ мм, на десятий день - $(1,32 \pm 0,09)$ мм (рис. 8).

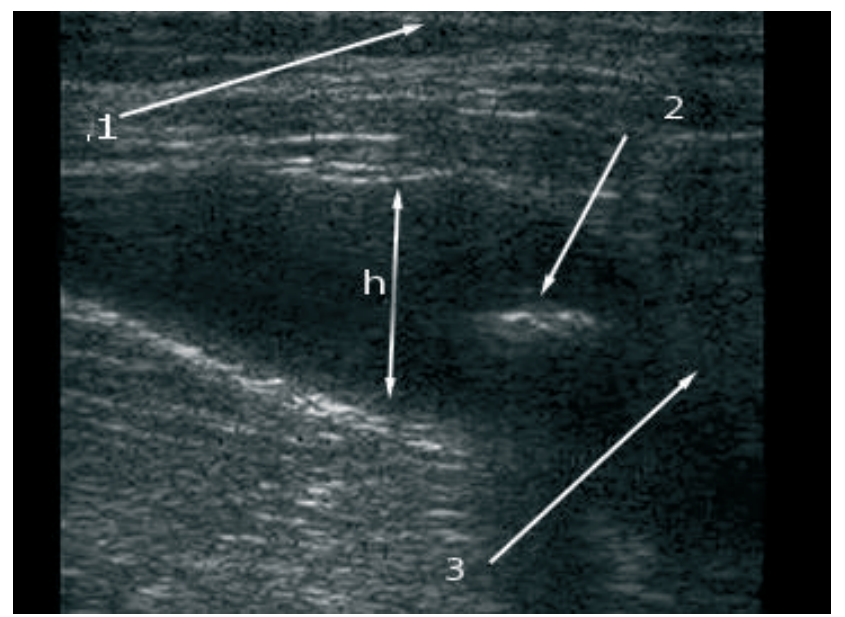

Рис. 6. Висота шару реактивного ексудату на першу добу після втручання в порожнині суглоба контрольної групи: h - висота шару реактивного ексудату в верхньому завороті колінного суглоба; 1 - сухожилок чотириголового м'яза стегна; 2 - фібриновий згусток та реактивна рідина в верхньому завороті колінного суглоба; 3 верхній полюс надколінника.

У контрольній групі, в порівнянні з першим післяопераційним днем, кількість реактивного ексудату на третій день становила в середньому $(2,32 \pm 0,11)$ мм, на десятий день $(1,64 \pm 0,10)$ мм. Тобто, на третю добу кількість реактивного ексудату в пацієнтів експериментальної групи була у 1,26 раза меншою, ніж у контрольній групі, на десятий день - у 1,24 раза (рис. 9).

Зменшення накопичення реактивної синовіальної рідини в верхніх заворотах колінного суглоба під впливом застосування кріотерапії з регульованим імпульсним стисненням дозволило в клініці зменшити кількість пункцій колінного суглоба на третю добу в експериментальній групі в



Рис. 7. Висота шару реактивного ексудату в осіб експериментальної групи на третю добу після втручання в порожнині суглоба: $\mathrm{h}$ - висота шару реактивного ексудату в верхньому завороті колінного суглоба; 1 верхній полюс надколінника; 2 - синовіальна оболонка колінного суглоба; 3 - реактивна рідина в верхньому завороті колінного суглоба; 4 - сухожилок чотириголового м'яза стегна.

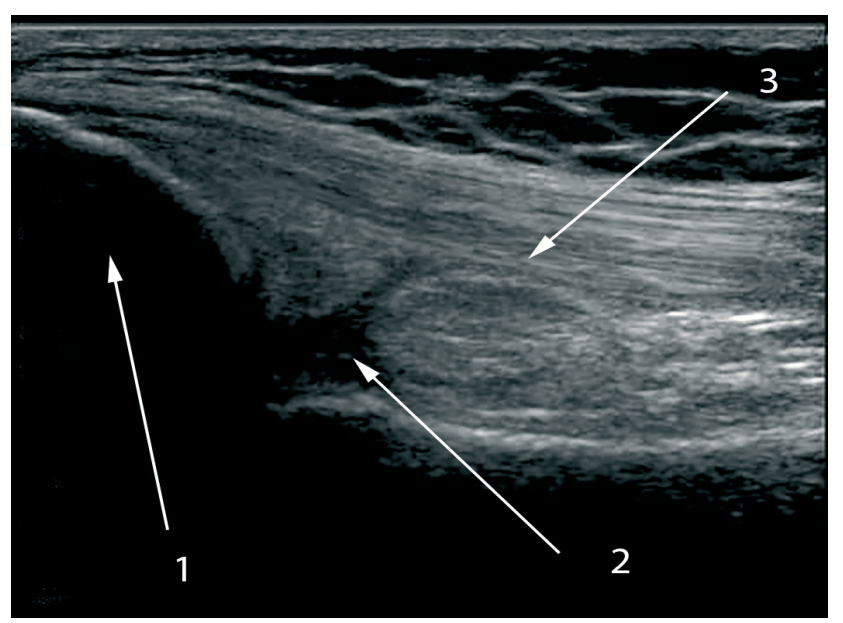

Рис. 8. Сонограма колінного суглоба пацієнта експериментальної групи на десяту добу після парціальної меніскектомії: 1 - надколінник; 2 - рідина в верхньому завороті колінного суглоба; 3 - сухожилля чотириголового м'яза стегна.

2,5 раза, та не проводити її взагалі на десятий день після втручання. В контрольній групі на третій день після втручання пункції колінного суглоба з метою евакуації надмірної кількості синовіальної рідини було проведено у 17 пацієнтів. На десятий день таку процедуру було повторно виконано у 4 прооперованих пацієнтів.

Висновки. 1. Прогресуюче зменшення інтенсивності больового синдрому на тлі використання кріотерапії з регульованим імпульсним стисненням у пацієнтів експериментальної групи дозволило в перші дніпісля оперативного втручання вдвічі зменшити застосування знеболювальних препаратів. 


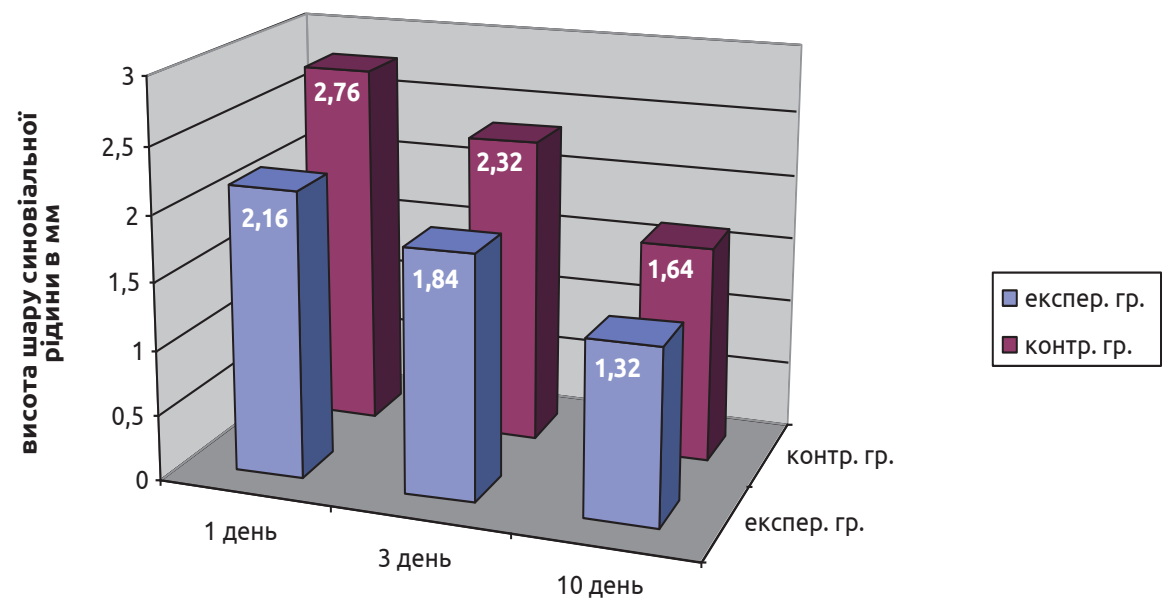

Рис. 9. Динаміка зміни висоти шару реактивного ексудату в верхніх заворотах колінного суглоба експериментальної та контрольної груп.

2. У результаті проведеного дослідження встановлено, що в обох групах на усіх етапах дослідження товщина синовіальної оболонки після парціальної меніскектомії була приблизно однакової товщини.

3. Застосування кріотерапії з регульованим імпульсним стисненням викликало зменшення накопичення реактивної синовіальної рідини у верхніх заворотах колінного суглоба, що дозволило зменшити кількість пункцій колінного суглоба в експериментальній групі в 2,5 раза, порівняно 3 контрольною.

Отже, кріотерапія з регульованим імпульсним стисненням показала свою ефективність при за- стосуванні з метою ранньої реабілітації пацієнтів після проведеної парціальної меніскектомії та може бути рекомендованою для використання у клінічній практиці.

Перспективи подальших досліджень. Важливим напрямком подальших досліджень $€$ встановлення оптимального температурного режиму кріоагента при використанні кріотерапії та частоти застосування даної процедури, вивчення впливу кріотерапії на якість та ефективність фізичної реабілітації при артроскопічних втручаннях на колінному суглобі.

\section{ЛІТЕРАТУРА}

1. Букина И.Е. Возможности артросонографии для диагностики субклинического синовита у больных гонартрозом на ранних стадиях (предварительные данные) / И. Е. Букина, Э. С. Мач, О. В. Пушкова // Научнопрактическая ревматология. - 2002. - № 2. - С. 10-134.

2. Вікторов О. П. Проблеми застосування анальгетиків-антипіретиків відповідно до критеріїв їх безпеки / О. П. Вікторов, В. Г. Кучер, О. В. Кашуба // Украинский ревматологический журнал. - 2006. - № 2 (24). C. 4-9.

3. Герасименко М. А. Диагностика и лечение повреждений и ортопедических заболеваний коленного сустава / М. А. Герасименко, А. В. Белецкий.- Минск: Технология, 2010. - 167 с.

4. Внутрисуставное лечение синовита с помощью лорноксикама у пациентов с остеоартритом коленных суставов / И. Ю. Головач, Т. М. Чипко, И. М. Зазирный, Е. А. Лазоренко // Актуальні проблеми клінічної та профілактичної медицини. - 2014. - № 1, Т. 2. - С. 40-46.
5. Карусинов П. С. Диагностика повреждений менисков и связок коленного сустава на магнитно-резонансных томографах с различной напряженностью магнитного поля / П. С. Карусинов // Воен. мед. журнал. 2001. - № 12. - С. 55.

6. Лялина В. В. Артроскопия и морфология синовитов / В. В. Лялина, А. Б. Шехтер. - М. : Наука, 2007. $108 \mathrm{c}$.

7. Страфун С. С. Реабілітація хворих при ізольованих та поєднаних ушкодженнях менісків з ушкодженнями хряща колінного суглоба / С. С. Страфун, О. А. Костогриз // Травма. - 2012. - № 4, Т. 13. - С 45-47.

8. Bollen S. Epidemiology of knee injuries: diagnosis and triage / S. Bollen // Br. J. Sports Med. - 2000. Vol. 34 (3). - P. 227-228.

9. Meniscal injury: I. basic science and evaluation / P. E. Greis, D. D. Bardana, M. C. Holmstrom, R. T. Burks // J. Am. Acad. Orthop. Surg. - 2002. - Vol. 10 (3). P. 168-176. 
Огляди літератури, оригінальні дослідження, погляд на проблему, випадок з практики, короткі повідомлення

10. Peripheral nerve blocks result in superior recovery profile compared with general anesthesia in outpatient knee arthroscopy / A. Hadzic, P. E. Karaca, P. Hobeika [et al.] // Anest. Analg. - 2005. - Vol. 100 (4). - P. 976-981.

11. Measures of adult pain: Visual Analog Scale for Pain (VAS Pain), Numeric Rating Scale for Pain (NRS Pain), McGill Pain Questionnaire (MPQ), Short-Form McGill Pain Questionnaire (SF-MPQ), Chronic Pain Grade Scale (CPGS), Short Form-36 Bodily Pain Scale (SF-36 BPS), and Measure of Intermittent and Constant Osteoarthritis Pain (ICOAP) / G. A. Hawker, S. Mian, T. Kendzerska, M. French // Arthritis Care Res. (Hoboken). - 2011. - Vol. 63 (Suppl 11). P. 240-252.

\section{REFERENCES}

1. Bukina, I.Ye., Mach, E.S., \& Pushkova, O.V. (2002). Vozmozhnosti artrosonografii dlya diagnostiki subklinicheskogo sinovita u bolnykh gonartrozom na rannikh stadiyakh (predvaritelnyie dannyie) [Possibilities of arthrosonography for the diagnosis of subclinical synovitis in patients with gonarthrosis in the early stages (preliminary data)]. Nauchno-prakticheskaya revmatologiya - Scientific and Practical Rheumatology, 2, 10-134 [in Russian].

2. Viktorov, O.P., Kucher, V.H., \& Kashuba, O.V. (2006). Problemy zastosuvannia analhetykiv-antypiretykiv vidpovidno do kryteriiv yikh bezpeky [Problems of application of analgesics-antipyretics in accordance with the criteria of their safety]. Ukraynskyy revmatolohycheskyy zhurnal Ukrainian Journal of Rheumatology, 2 (24), 4-9 [in Ukrainian].

3. Gerasimenko, M.A., \& Beletskiy, A.V. (2010). Diagnostika i lecheniye povrezhdeniy $i$ ortopedicheskikh zabolevaniy kolennogo sustava [Diagnosis and treatment of injuries and orthopedic diseases of the knee joint]. Minsk: Tekhnologiya [in Russian].

4. Holovach, I.Yu., Chipko, T.M., Zazirnyi, I.M., \& Lazorenko, Ye.A. (2014). Vnutrisustavnoie lecheniye sinovita s pomoshchu lornoksikama u patsiyentov s octeoartritom kolennykh sustavov [Intra-articular treatment of synovitis with lornoxicam in patients with osteoarthritis of the knee joints]. Aktualni problemy klinichnoi ta profilaktychnoi medytsyny - Current Problems of Clinical and Preventive Medicine, 1, 2, 40-46 [in Russian].

5. Karusinov, P.S. (2001). Diagnostika povrezhdeniy meniskov i sviazok kolennogo sustava na magnitno-rezonansnykh tomografakh s razlichnoy napriazhennostiu magnitnogo polya [Diagnostics of injuries of the menisci and ligaments of the knee joint on magnetic resonance imaging machines with different magnetic field strength]. Voien. med. zhurnal - Military Med. J., 12, 55 [in Russian].

6. Lyalina, V.V., \& Shekhter, A.B. (2007). Artroskopiya i morfologiya sinovitov [Arthroscopy and morphology of synovitis]. Moscow: Nauka [in Russian].
12. Meniscectomy versus meniscal repair: 10 years radiological and clinical results in vertical lesions in stable knee / C. Lutza, F. Dalmay, F. Ehkirch [et al.] // Orthop Traumatol Surg Res. - 2015. - Vol. 101 (Suppl. 8). - P. 327-331.

13. Marzo J. M. Effects of medial meniscus posterior horn avulsion and repair on tibiofemoral contact area and peak contact pressure with clinical implications / J. M. Marzo, J. Urske-DePerio // Am. J. Sports Med. - 2009. - Vol. 37 (1). - P. 124-129.

14. McGeown J. G. Effects of varying patterns of external compression on lymph flow in the hindlimb of the anaesthetized sheep / J. G. McGeown, N. G. McHale, K. D. Thornbury // J. Physiol. - 1988. - P. 449-457.

7. Strafun, C.C., \& Kostohryz, O.A. (2012). Reabilitatsiia khvorykh pry izoliovanykh ta poiednanykh ushkodzhenniakh meniskiv z ushkodzhenniamy khriashcha kolinnoho suhloba [Rehabilitation of patients with isolated and combined injuries of the menisci with damage to the cartilage of the knee joint]. Travma - Trauma, 4, 13, 45-47 [in Ukrainian].

8. Bollen, S. (2000). Epidemiology of knee injuries: diagnosis and triage. Br. J. Sports Med., 34 (3), 227-228.

9. Greis, P.E., Bardana, D.D., Holmstrom, M.C., \& Burks, R.T. (2002). Meniscal injury: I. basic science and evaluation. J. Am. Acad. Orthop. Surg., 10 (3), 168-176.

10. Hadzic A., Karaca, P.E., Hobeika, P., Unis, G., Dermksian, J., Yufa, M., \& Thys, D.M. (2005). Peripheral nerve blocks result in superior recovery profile compared with general anesthesia in outpatient knee arthroscopy. Anest. Analg., 100 (4), 976-981.

11. Hawker, G.A., Mian, S., Kendzerska, T., \& French, M. (2011). Measures of adult pain: Visual Analog Scale for Pain (VAS Pain), Numeric Rating Scale for Pain (NRS Pain), McGill Pain Questionnaire (MPQ), Short-Form McGill Pain Questionnaire (SF-MPQ), Chronic Pain Grade Scale (CPGS), Short Form-36 Bodily Pain Scale (SF-36 BPS), and Measure of Intermittent and Constant Osteoarthritis Pain (ICOAP). Arthritis Care Res (Hoboken), 63, 11, 240-252.

12. Lutz, C., Dalmay, F., Ehkirch, F.P., Cucurulo, T., Laporte, C., Le Henaff, G., \& Sonnery-Cottet, B. (2015). Meniscectomy versus meniscal repair: 10 years radiological and clinical results in vertical lesions in stable knee. Orthop Traumatol Surg Res., 101 (8), 327-331.

13. Marzo, J.M., \& Urske-DePerio, J. (2009). Effects of medial meniscus posterior horn avulsion and repair on tibiofemoral contact area and peak contact pressure with clinical implications. Am. J. Sports Med., 37 (1), 124-129.

14. McGeown, J.G., McHale, N.G., \& Thornbury, K.D. (1988). Effects of varying patterns of external compression on lymph flow in the hindlimb of the anaesthetized sheep. J. Physiol., 449-457. 
Тернопольский национальный медицинский университет имени И. Я. Горбачевского МОз Украины

РЕзЮМЕ. Среди всех травм нижней конечности частота повреждений коленного сустава составляет до $75 \%$ случаев. Среди повреждений коленного сустава преобладают разрывы менисков, на их долю приходится от $32 \%$ до 85 \% случаев травм. С середины 1980-х годов артроскопические хирургические вмешательства стали «золотым стандартом» в лечении разрывов менисков и окончательно показали свою эффективность по сравнению с открытой артротомией. Однако оперативное вмешательство, даже малотравматическое, вызывает болевой синдром и развитие реактивного синовиита коленного сустава, устранение которого в кратчайшие сроки позволяет ускорить реабилитацию. Считается что использование холода - это одно из самых распространенных средств, которое используется как эффективное нефармакологическое средство для лечения болевого синдрома при травмах. Чаще всего указывают на следующие эффекты от применения криотерапии - снятие боли, уменьшение воспалительного отека и ликвидация мышечного спазма. Результат холодового воздействия зависит как от количества и скорости тепла, отводимого с травмированного участка, так и от характера общей и местной реакции организма на воздействие низких температур.

Цель - изучить эффективность применения криотерапии с регулируемым импульсным сжатием у пациентов после артроскопической парциальной менискектомии для снижения интенсивности болевого синдрома и проявлений послеоперационного реактивного синовиита.

Материал и методы. Всего под наблюдением находилось 50 пациентов. Они были поделены на две группы: контрольную и экспериментальную, по 25 пациентов в каждой. В экспериментальную группу вошли 25 пациентов (18 мужчин и 7 женщин) в возрасте от 18 до 43 лет (средний возраст - 31,2 года). В контрольную группу сравнения вошли 25 пациентов (16 мужчин и 9 женщин) в возрасте от 18 до 42 лет (средний возраст - 32,6 года). С целью определения эффективности применения криотерапии с регулируемым импульсным сжатием при болевом синдроме и реакции синовиальной оболочки коленного сустава у пациентов после проведенной парциальной менискэктомии в первые часы в экспериментальной группе применяли систему «GIOCO CRYO - 2». При включении прибора участок сустава периодически сжимался манжетой с циклом в 30 секунд (10 секунд сжатие, 20 секунд релаксация). Скорость подачи охлажденной жидкости составляла до 7 литров в минуту. Ее температура колебалась в пределах 11-13 градусов Цельсия. В контрольной группе применяли мешочки со льдом. Продолжительность проведения процедуры в обеих группах составила 15 минут.

Выводы. Данные, полученные в ходе исследования, свидетельствуют о целесообразности внедрения в повседневную практику криотерапии с регулируемым импульсным сжатием с целью ранней реабилитации пациентов после проведенной парциальной менискэктомии.

КЛючЕВЫЕ СЛОВА: травма, повреждения менисков, коленный сустав, криотерапия с регулируемым импульсным сжатием, артроскопия, менискэктомия.

\section{PAIN SYNDROME AND RESPONSE OF THE SYNOVIAL MEMBRANE OF THE KNEE JOINT TO USING CRYOTHERAPY WITH ADJUSTABLE PULSE COMPRESSION IN PATIENTS UNDERGOING ARTHROSCOPIC PARTIAL MENISCECTOMY}

๑Y. O. Hrubar, Y. Y. Hrubar

\section{Horbachevsky Ternopil National Medical University}

SUMMARY. Among all injuries of the lower extremity, the frequency of injuries of the knee joint is up to $75 \%$ of cases. The most common knee injuries are meniscal ruptures, accounting for $32 \%$ to $85 \%$ of injuries. Since the mid- 1980 s, arthroscopic surgery has become the "gold standard" in the treatment of meniscal rupture and has finally shown its effectiveness compared to open arthrotomy. However, surgery, even minimally invasive, causes pain and the development of reactive synovitis of the knee joint, the elimination of which in the shortest possible time can speed up rehabilitation. It is believed that the use of cold is one of the most common means used as an effective non-pharmacological intervention for the treatment of pain in injuries. The most commonly indicated effects of cryotherapy are pain relief, reduction of inflammatory edema, and elimination of muscle spasm. The result of cold exposure depends on the amount and speed of heat removed from the injured area, as well as on the nature of the general and local reaction of the body to the effects of low temperatures.

The aim - to study the effectiveness of cryotherapy with adjustable pulse compression in patients after arthroscopic partial meniscectomy to reduce the intensity of pain and postoperative reactive synovitis. 
Огляди літератури, оригінальні дослідження, погляд на проблему, випадок з практики, короткі повідомлення

Material and Methods. A total of 50 patients were monitored. They were divided into two groups: control and experimental 25 patients in each. The experimental group included 25 patients (18 men and 7 women) aged 18 to 43 years (mean age -31.2 years). The control group included 25 patients (16 men and 9 women) aged 18 to 42 years (mean age 32.6 years). In order to determine the effectiveness of cryotherapy with controlled pulse compression in pain and the reaction of the synovial membrane of the knee joint in patients after partial meniscectomy in the first hours in the experimental group used the system "GIOCO CRYO - 2". When the device was turned on, the joint area was periodically compressed with a cuff with a cycle of 30 seconds (10 seconds of compression, 20 seconds of relaxation). The cooling rate of the cooled liquid was up to 7 liters per minute. Its temperature ranged from 11 to 13 degrees Celsius. Ice bags were used in the control room. The duration of the procedure in both groups was 15 minutes.

Conclusions. The data obtained during the study indicate the feasibility of introducing into everyday practice cryotherapy with adjustable pulse compression for early rehabilitation of patients after partial meniscectomy.

KEY WORDS: trauma; meniscus damage; knee joint; cryotherapy with adjustable pulse compression; arthroscopy; meniscectomy.

Отримано 12.02.2021 